\title{
Everolimus/Exemestane Regimen
}

National Cancer Institute

\section{Source}

National Cancer Institute. Everolimus/Exemestane Regimen. NCI Thesaurus. Code C142863.

A chemotherapy regimen consisting of everolimus and exemestane that is used as a treatment for hormone receptor (HR)-positive and HER-2/neu-negative metastatic or advanced breast cancer. 